\title{
Which Disinfection Method is Effective for Water Disinfection
}

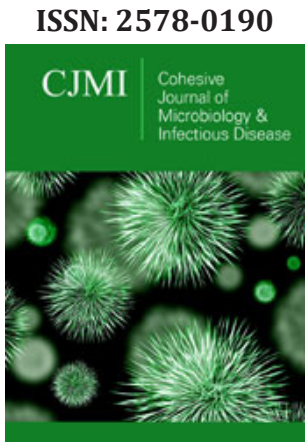

${ }^{* 1}$ Corresponding author: Gülnur Tarhan, Faculty of Medicine, Department of Medical Microbiology, Adiyaman University, Turkey

Submission: 潐April 14, 2019

Published: 䟧May 10, 2019

Volume 2 - Issue 4

How to cite this article: Gülnur Tarhan Which Disinfection Method is Effective for Water Disinfection. Cohesive J Microbiol Infect Dis. 2(4). CJMI.000544.2019. DOI: 10.31031/CJMI.2019.02.000544

Copyright@ Gülnur Tarhan, This article is distributed under the terms of the Creative Commons Attribution 4.0 International License, which permits unrestricted use and redistribution provided that the original author and source are credited.

\author{
Gülnur Tarhan* \\ Department of Medical Microbiology, Adiyaman University, Turkey
}

\begin{abstract}
An effective drinking and pool water disinfection is the most important public health reponsibility. The raw water obtained from natural sources is treated by using three basic steps: sedimentation, ventilation and filtration. With good treatment, the number of bacteria in water can be reduced by $99.5 \%$. The water must be disinfected after pretreatment. Disinfection is generally carried out by chemical, physical or mechanical methods. The chemicals used in the disinfection process are chlorine and chlorine compounds, bromine and iodine compounds, ozone, phenol and phenolic compounds, alcohols, various dyes, soaps and synthetic detergents, ammonium compounds, hydrogen peroxide, various alkalis and acids. The use of heat and light are physical disinfection methods. With in these methods, chlorination is the most common, effective and cheapest disinfection method of water. At the same time, it is an effective microbiocide against all water-borne pathogens, although it can cause by-products after disinfection of drinking or pool water disinfection. In general, other disinfection methods are used as a supplement.
\end{abstract}

Keywords: Pool; Drinking water; Disinfection

\section{Introduction}

Water is one of the most basic requirements for the individual to sustain his or her life. Global warming, pollution of resources, unplanned growth, social and political instabilities can be used and increased scars of access to potable clean water. Global warming, pollution of resources, unplanned growth, social and political instability can be used and increased access to drinking water. The concept of water deprivation has come to the fore due to all these reasons. For all these reasons, water deprivation has become a major problem in recent years [1-4]. Dissolved and undissolved inorganic salts, bacteria, parasites, viruses and organic substances in contaminated water cause many diseases. About $20 \%$ of the world's population uses unreliable drinking water, about 200 million people are infected with water-related diseases annually, and more than 2 million people die annually due to diseases (typhoid, dysentery, cholera, etc.) related to contaminated waters.For this reason, in order to protect public health, there should be no harmful microorganisms in drinking water. Potential disease-causing microorganisms that can be found in domestic wastewater are shown in Table 1 [5-11].

\section{Potential disease-causing microorganisms in wastewater (Table1)}

For this purpose, the raw water obtained from natural sources is treated by using various physical and chemical methods in accordance with water quality standards and regulations. This process consists of three basic steps: sedimentation, ventilation and filtration. Drinking and use water is passed through the same steps and subjected to treatment. With good treatment, the number of bacteria in water can be reduced by $99.5 \%$ [12-16].

The water must be disinfected after pretreatment. There are many physical and chemical methods that can be used individually for disinfection of water. However, a small number of disinfection techniques can be used in social applications. A disinfectant needs to carry some properties in order to be used in drinking and potable water disinfection. For this reason, it is essential to offer safe water with balanced mineral distribution, not exceeding certain limit values, no disease-causing microorganisms and suitable physical qualities [17].

Drinking and using water is mainly obtained from groundwater and surface water. Groundwater is obtained from boreholes drilled from underground aquifers with a depth 
of tens or hundreds of meters. These wells usually displace water in deep aquifers from the surface, and this occurs slowly over hundreds or thousands of years. Groundwater shows less pollution than surface waters. Since the organic matter on the surface takes a long time to break down by bacteria and reach groundwater, groundwater is more protected from surface pollution. The soil itself acts as a filter and allows for less pollution [18]. Surface waters consist of lakes, rivers and reservoirs. It usually has more suspended solids than ground water, and needs to be treated more safely to drink safely. Surface water is used for other purposes than drinking water and is often contaminated with sewage and industrial wastewater. As the rivers go from the beginning to the end, pollution increases because of the repeated use of water. Raw water obtained from natural water sources is purified from substances which are harmful to health by using various physical and chemical methods before being put into use. Although various methods are used to prepare water sources for drinking, the basic principles are the same $[19,20]$.

Table1: Potential disease-causing microorganisms in wastewater

\begin{tabular}{|c|c|c|}
\hline & Microorganism & Caused Disease \\
\hline \multirow{6}{*}{ Bacteria } & Escherichia coli & $\begin{array}{l}\text { Gastrointestinal and intes- } \\
\text { tinal inflammation }\end{array}$ \\
\hline & Leptospira & Leptospirosis \\
\hline & Salmonella typhi & Tifo \\
\hline & Salmonella $(=2,100$ serotypes $)$ & Salmonellosis \\
\hline & Shigella (4 spp.) & $\begin{array}{l}\text { Shigellosis (bacillary } \\
\text { dysentery) }\end{array}$ \\
\hline & Vibrio cholerae & Kolera \\
\hline \multirow{4}{*}{ Protozoa } & Balantidium coli & Balantidiasis \\
\hline & Cryptosporidium parvum & Cryptosporidiosis \\
\hline & Entamoeba histolytica & $\begin{array}{l}\text { Amebiasis (amoebic } \\
\text { dysentery) }\end{array}$ \\
\hline & Giardia lamblia & Giardiasis \\
\hline \multirow{3}{*}{$\begin{array}{l}\text { Helmint- } \\
\text { hs }\end{array}$} & Ascaris lumbricoides & Ascariasis \\
\hline & T. solium & Taeniasis \\
\hline & Trichuris trichiura & Trichuriasis \\
\hline \multirow{4}{*}{ Viruses } & $\begin{array}{l}\text { Enteroviruses (72 type, polio, } \\
\text { echo, coxsackie viruses etc.) }\end{array}$ & $\begin{array}{l}\text { Gastroenteritis, heart } \\
\text { anomalies, meningitis }\end{array}$ \\
\hline & Hepatitis A virüs & Infectious hepatitis \\
\hline & Norwalk agent & Gastroenteritis \\
\hline & Rotavirus & Gastroenteritis \\
\hline
\end{tabular}

When determining the method to be used; Water quality, turbidity (particle quantity), water temperature, $\mathrm{pH}$ level and type of pathogenic microorganisms in water should be taken into consideration. General water treatment applied for surface waters consists of three basic steps: flocculation or coagulation (the addition of aluminum sulfate or metal salts to the water to collect particles in water), sedimentation (It is the process of collapsing the water at the bottom of the tank with the effect of gravity of the particles coming together at the end of the first stage) and filtration(solid particles are removed from the water as a result of sedimentation with slow or rapid sand filters or with active charcoal filters) [21,22].

Drinking and use water is passed through the same steps and subjected to treatment. With good treatment, the number of bacteria in water can be reduced by $99.5 \%$. Water is disinfected after pretreatment and its quality is increased. Disinfection is the process that is applied to neutralize the microorganisms in water. The efficacy of disinfection is defined by the action of killing $99 \%$ of the microbicide within 30 seconds. Disinfection is generally carried out by chemical, physical, mechanical methods or by radiation. The chemicals used in the disinfection process are chlorine and chlorine compounds, bromine and iodine compounds, ozone, phenol and phenolic compounds, alcohols, various dyes, soaps and synthetic detergents, ammonium compounds, hydrogen peroxide, various alkalis and acids. The use of heat and light (especially ultraviolet) are physical disinfection methods. Partial reduction of microorganisms is possible by mechanical processes such as precipitation, flocculation and filtration. Gamma rays from radioisotopes such as cobalt 60 are also used in water and wastewater disinfection [2025]. Water disinfection methods were shown in Table 2.

\section{Water disinfection methods (Table 2)}

Table 2: Water disinfection methods

\begin{tabular}{|c|c|}
\hline Chemical Methods & $\begin{array}{l}\text { - Chlorine and chlorine compounds } \\
\text { - Brom } \\
\text { - Iodine } \\
\text { - Ozone } \\
\text { - Phenol and phenolic compounds } \\
\text { - Alcohols } \\
\text { - Heavy metals } \\
\text { - Stains } \\
\text { - Soaps and detergents } \\
\text { - Ammonium compounds } \\
\text { - Hydrogen peroxide } \\
\text { - Peracetic acid }\end{array}$ \\
\hline Physical Methods & $\begin{array}{l}\text { - Temperature } \\
\text { - Light (ultraviolet and sunlight) } \\
\text { - Sound waves }\end{array}$ \\
\hline
\end{tabular}




\begin{tabular}{|c|c|}
\hline $\begin{array}{l}\text { Mechanical Met- } \\
\text { hods }\end{array}$ & $\begin{array}{l}\text { - Sand holder } \\
\text { - Pre-sedimentation } \\
\text { - Activated sludge system } \\
\text { - Chemical precipitation } \\
\text { - Stabilization pools } \\
\text { - Trickle filter }\end{array}$ \\
\hline Radiation & $\begin{array}{l}\text { - Gamma rays } \\
\text { - High energy electron beam }\end{array}$ \\
\hline
\end{tabular}

Generally, few disinfection techniques can be used in public health practices. A disinfectant needs to carry some properties in order to be used in drinking and potable water disinfection. It should be suitable for the removal of pathogenic organisms in the expected temperature range and the contact time provided in the composition and quantity of water to be disinfected, durable, economical and easy to use; easy, accurate and patriarchal analysis of the disinfectant should be possible in order to control disinfection time and effectiveness. One of the most important features of the disinfectant applied to the dose, does not show toxic properties. For this purpose, chlorination, UV and ozone are suitable for disinfection of large water bodies [17-25]. Others are suitable for environments where small water bodies or toxicity from disinfectants are ensured. Apart from chlorine and some compounds, there are some limitations in the use of other disinfectants and disinfection methods in drinking water treatment plants. For this reason, a very large percentage of disinfection processes are done with chlorine in water treatment plants. Disinfection with chlorine is the most widely used disinfection method in our country [26-30]. However, compounds that make cancer by adding chlorine to water (monochloro, dichloro and trichloroacetic acid structures) are known as carcinogenic effective disinfection by-products. "Swimming Asthma" caused by inhalation of by-products of chlorine (trihalomethanes) used in swimming pools has been observed especially in young children [31-34].

Disinfection By-Products (DBP's) are defined as the structures formed as a result of the reaction of organic or inorganic structures in the chemical composition of water with disinfectants. Factors affecting water disinfection; contact time, type and concentration of chemical disinfectant, density and structure of physical disinfectant, temperature, number of microorganisms, microorganism type and characteristics of water Table 4 [35].

\section{Major factors affecting disinfection (Table 3)}

Water must be protected from any contamination, especially microbiological contamination, during the storage and distribution (network system) phases following water treatment operations.In addition to the microorganisms that may come from outside, a very thin layer of microorganisms, often called biofilm, develops in the water tanks and distribution pipes. The mosteffective method used to protect treated water from all these microbiological contamination sources is chlorination before dispensing. No residual preservation method has yet to be proven, except for chlorination. Especially in regions and countries where the integrity of the water distribution network is not fully ensured and water leaks from the network are present, chlorination is vital [7,36-38]. Conventional disinfection methods were shown in Table IV.

Table 3: Major factors affecting disinfection

\begin{tabular}{|c|c|}
\hline Type of disinfectant & $\begin{array}{c}\text { Disinfection efficiency depends on the type } \\
\text { of chemical used. Each disinfectant has a } \\
\text { separate strength and property. Some disin- } \\
\text { fectants such as ozone, chlorine dioxide are } \\
\text { stronger oxidants than chlorine }\end{array}$ \\
\hline $\begin{array}{c}\text { Type and number of } \\
\text { microorganisms }\end{array}$ & $\begin{array}{c}\text { The resistance of microbial pathogens to } \\
\text { disinfectants varies greatly. Spore-forming } \\
\text { bacteria are more resistant to disinfectants } \\
\text { than vegetative bacteria. Microorganis- } \\
\text { ms are resistant to disinfectants in the } \\
\text { following order. Vegetative bacteria-enteric } \\
\text { viruses-spore-forming bacteria-protozoal } \\
\text { cysts }\end{array}$ \\
\hline $\begin{array}{c}\text { Contact time and disin- } \\
\text { fectant concentration }\end{array}$ & $\begin{array}{c}\text { The pH and temperature of the environ- } \\
\text { ment are the most important factors affec- } \\
\text { ting the effectiveness of disinfectants. }\end{array}$ \\
\hline $\begin{array}{c}\text { Pathogen inactivation with disinfectants } \\
\text { increases with time and takes place with } \\
\text { first order kinetics. }\end{array}$ \\
\hline Physical and chemical \\
interference & $\begin{array}{c}\text { Inorganic and organic nitrogen compounds, } \\
\text { iron, compounds such as manganese and } \\
\text { hydrogen sulfide interfere with disinfecti- } \\
\text { on. Dissolved organic compounds increase } \\
\text { the chlorine requirement and their presen- } \\
\text { ce decreases the disinfection efficiency.The } \\
\text { turbidity in the water consists of microbial } \\
\text { cells and inorganic (silt, clay, iron oxide, } \\
\text { etc.) and organic matter. }\end{array}$ \\
\hline
\end{tabular}

\section{Conventional disinfection methods (Table 4)}

All chemical disinfectants (chlor-Cl2, monochloramine- $\mathrm{NH} 2 \mathrm{Cl}$, ozone-03, chlorine dioxide-ClO2) are known to form various by-products.The most important precursors are natural organic matter and bromide.By-product formation; $\mathrm{pH}$, temperature, time, disinfectant type, dose and dose, contact time, application point of disinfectant etc. depends on the parameters.Some by-products are halogen-substituted by-products, while others are by-products of oxidation.Halogenated organic by-products are formed by the reaction of natural organic material (NOM) with free chlorine and free bromine.The free chlorine can reach water directly with chlorine dioxide or chloramines as primary or secondary disinfectant.Free bromine is formed by oxidation of bromide ions in water. [2,25-29,31].

Formation of halogenated disinfection by-products; it depends on the type and concentration of the natural organic material, the type and dose of the oxidant, the time, the concentration of bromide ion, the $\mathrm{pH}$, the concentration of organic nitrogen and the temperature.Organic nitrogen causes the formation of nitrogencontaining disinfection by-products such as haloacetonitrile, halopicrin and cyclones.Non-halogenated disinfection by-products are also the result of the interaction of organiccompounds in water with strong oxidants.Most oxidizing by-products are biodegradable and are present in the treated water as biodegradable dissolved 
organic carbon (BDOC) and as assimilable organic carbon (AOC). Free chlorine and free bromine are produced in chloramine. Therefore, the formation of the disinfection by-products that occur in chlorination is also expected here. However, they are in lower concentrations [2,25-29,31]. Chloramines are weaker oxidants than chlorine and are more likely to be involved in chlorine substitution reactions than oxidation reactions, similar to chlorine, Substitution reactions are particularly common with organic nitrogen compounds. The chlorinated aldehydes, chlorinated acids and chlorinated ketone by-products were determined when chloramine was applied to the waters containing fulvic acid [32-38]. Products produced by ozonation of drinking water include simple aldehydes, small molecular weight aliphatic acids, some keto-acids, hydroxy-acids, organic peroxides and benzene polycarboxylic acids. It is suspected that only this group of peroxides, bromoorganics and aldehydes may be harmful to human health [39-43]. In particular, formaldehyde may be a product that is always present. Some of these by-products (such as peroxides, formaldehyde) can be consumed by slow reaction with other components in water. When water containing high amounts of bromide is ozonated, the formation of brominated organic by-products will occur.This is the result of oxidation of bromide to hypobromous acid followed by reaction of natural organic matter with hypobromous acid. At typical $\mathrm{pH}$ and ozone dose values, approximately $7 \%$ of the bromide in the raw water is converted to total organic bromine (TOBr). The formation of TOBr increases with high bromide levels, low $\mathrm{pH}$ and high ozone dose.It has already been recognized that ozone, under certain conditions, has produced new precursors and caused an increase in THM formation.It has long been known that ozone destroys THM precursors in drinking water [44-50]. Studies have shown that the need for chlorine decreases with preozonation.After ozonation, it was observed that chlorination at low $\mathrm{pH}$ caused the most decrease in THM formation.In systems with high $\mathrm{pH}$ chlorination (above $\mathrm{pH}$ 8.5), it is possible to see a clear increase in THM formation.In water treatment applications, there is little literature on UV-related by-products [51-54]. In 1994, the Montgomery Watson Company reported that trihalomethanes were not formed if UV radiation was applied to recovered wastewater. Significantly, it reduces aldehyde formation and does not emerge from other FDIs [55]. The application of UV radiation to surface waters under certain conditions highlights a number of reduction reactions and as a result, bromate can be reduced to bromide.Since bromate absorbs UV radiation only within the 200-240 nm range, these reactions cannot be initiated with lowpressure mercury lamps.Medium pressure lamps can cause these reactions [56,57]. In a study conducted by AWWA to assess the effects of low-pressure mercury lamps on by-product formation, no formation of bromate or bromine by-products was observed in any of the groundwater samples [55]. In addition, no change in bromate concentrations was observed in samples containing bromate before UV.In the same study, UV radiation was observed to form low levels of formaldehyde in most surface water samples.The highest formaldehyde concentrations were found in untreated surface waters.Water exposure to water may result in the formation of ozone or radical oxidants. Formaldehyde is a common ozonation byproduct.Consequently, conventional UV technology is a promising method which does not constitute a by-product, which may be an alternative to other methods.

Table 4: Conventional disinfection methods.

\begin{tabular}{|c|c|}
\hline Boiling process & $\begin{array}{l}\text { If the water is boiled for 15-20 minutes, the bacteria it contains are inactivated. This method is often used in homes. Heat } \\
\text { disinfection is a very expensive method for large-scale applications, but is widely used in the food industry. Heat disinfection } \\
\text { is associated with heat resistance of microorganisms or spores. }\end{array}$ \\
\hline Acid and alkali addition & $\begin{array}{l}\text { Water with } \mathrm{pH}<3 \text { or } \mathrm{pH}>11 \text { is toxic to many bacteria and can be used in pathogen inactivation. Disinfection of drinking } \\
\text { water with the addition of acid and alkali is not a common practice. However, it is a spontaneous phenomenon in lime-soda } \\
\text { softening processes. Addition of lime to water reduces some microorganisms in water. Requires long contact times. Cationic } \\
\text { detergents are used as disinfectants in health institutions. Cationic detergents are strong disinfectants and anionic deter- } \\
\text { gents are poor disinfectants. }\end{array}$ \\
\hline $\begin{array}{l}\text { Potassium perman- } \\
\text { ganate }\end{array}$ & $\begin{array}{l}\text { It is a strong oxidizer and disinfectant. However, the removal rate of permanganate E.coli is lower than that of ozone and } \\
\text { chlorine. Therefore, it is very rare to use it for disinfection in drinking water treatment plants. It does not form taste, odor } \\
\text { and toxic compounds in water }\end{array}$ \\
\hline $\begin{array}{l}\text { Bromine, Iodine, } \\
\text { Chlorine }\end{array}$ & $\begin{array}{l}\text { Bromine; It is a weaker disinfectant than chlorine. The monobrom amine formed due to the fact that it is a strong bactericidal } \\
\text { and tribromamine formation in water containing ammonia is used for small applications in swimming pools } \\
\text { Iodine; It does not react with organic substances as easily as chlorine. It is an advantageous disinfectant due to its high disin- } \\
\text { fection power. Iodine does not form iodamines with ammonia; however, it oxidizes ammonia. After disinfection, the residual } \\
\text { iodine is stable and it is also an advantage that it does not create odor. The fact that the effects of water treatment is not well } \\
\text { known is 10-15 times more expensive than chlorine. It is not used for possible effects on the thyroid gland. } \\
\text { Chlorine; It is preferred as disinfectant in all underground and surface water treatment systems. The attractive properties of } \\
\text { chlorine; Effectively inactivate a large part of the water pathogens, easy to measure, controllable residues and economic is to } \\
\text { leave. However, there are factors limiting the use of chlorine. These disadvantages are; } \\
\text { - Reacts with naturally occurring organic and inorganic compounds in water and forms undesirable disinfection by-products } \\
\text { - Requires special treatment of hazardous compounds due to chlorine use } \\
\text { - High chlorine doses cause taste and odor problems. }\end{array}$ \\
\hline
\end{tabular}


In conclusion, chlorination is the most common, effective and cheapest disinfection method of water. At the same time, it is an effective microbiocide against all water-borne pathogens, although it can cause by-products after disinfection of drinking or pool water disinfection. In general, other disinfection of disinfection are used as a supplement.

\section{References}

1. World Health Organization (2017) Guidelines for drinking-water quality and $1^{\text {st }}$ Addendum. ( $4^{\text {th }}$ edn), Geneva, Switzerland p. 631.

2. Hrudey SE (2012) Epidemiological inference and evidence on DBPs and human health. In: Hrudey SE, Charrois JWA (Eds.), Disinfection Byproducts and Human Health. IWAPublishing, London, UK, pp. 213281.

3. (2015) Progress on sanitation and drinking water update and MDG assessment. United Nations Children's Fund and World Health Organization (2015accessed 20 July 2017), Geneva, Switzerland.

4. Seyfried PL, Tobin RS, Brown NE, Ness PF (1985) A prospective study of swimming-related illness. I. Swimming-associated health risk. Am Public Health 75(9): 1068-1070.

5. Heckley W, Gilman RH, Black RE, Epstein LD, Cabrera L, et al. (2004) Effect of water and sanitation on childhood health in a poor Peruvian peri-urban community. Lancet 363(9403): 112-118.

6. Momba MNB, Mamba BB, Mwabi JK (2013) Removal of waterborne bacteria from surface water and groundwater by cost-effective household water treatment systems. A sustainable solution for improving water quality in rural communities of Africa. Water South Africa 39(4): 1-12.

7. Kumar Reddy DH, Lee S (2012) Water pollution and treatment technologies. Journal of Environmental \& Analytical Toxicology.

8. Kelishadi R, Amin MM, Haghdoost AA, Gupta AK, Tuhkanen TA(2013) Pollutants source control and health effects. Journal of Environmental and Public Health. Isfahan University, Iran.

9. Gu Q Deng J, Wang K, Lin Y, Ma L, et al. (2014) Identification and assessment of potential water quality impact factors for drinking-water reservoirs. Int J Environ Res Public Health 11(6): 6069-6084.

10. Prest EI, Hammes F, van Loosdrecht MC, Vrouwenvelder JS (2016) Biological stability of drinking water. Controlling Factors, Methods, and Challenges. Front Microbiol 7: 45.

11. Berry D, Xi C, Raskin L (2006) Microbial ecology of drinking water distribution systems. Current Opinion in Biotechnology 17(3): 297-302.

12. Majuru B, Michael Mokoena M, Jagals P, Hunter PR (2011) Health impact of small-community water supply reliability. Int J Hyg Environ Health 214(2): 162-166.

13. Reller ME, Mendoza CE, Lopez MB, Alvarez M, Hoekstra AR, et al. (2003) A randomized controlled trial of household-based flocculant-disinfectant drinking water treatment for diarrhoea prevention in rural Guatemala. Am J Trop Med Hyg 69(4): 411-419.

14. Boyd DR (2006) The water we drink: an international comparison of drinking water quality standards and guidelines. David Suzuki Foundation, Vancouver, Canada, pp. 1-34

15. Cook C, Bakker K (2012) Water security: Debating an emerging paradigm. Global Environmental Change 22(1): 94-102.

16. Dupont D, Waldner C, Bharadwaj L, Plummer R, Carter B, et al. (2014) Drinking water management: health risk perceptions and choices in First Nations and non-First Nations communities in Canada. Int J Environ Res Public Health 11(6): 5889-5903.

17. APHA (1998) Standard methods for the examination of water and wastewater, (20 ${ }^{\text {th }}$ Edn, $)$. American Public Health Association, Washington, USA.

18. Bartram J, Cairncross S (2010) Hygiene, sanitation, and water: forgotten foundations of health. PLoS Med 7(11): e1000367.

19. Bain RE, Gundry SW, Wright JA, Yang H, Pedley S, et al. (2012) Accounting for water quality in monitoring access to safe drinking-water as part of the Millennium Development Goals: lessons from five countries. Bulletin of the World Health Organization 90: 228-235A.

20.World Health Organization (1996) Water Sanitation and Health: Coagulation, flocculation and clarificaton. Geneva, Switzerland.

21. WHO/UNICEF (2015) The sanitation and drinking-water ladders Water Disinfection Series. WHO/UNICEF Joint Monitoring Programme, IN: Connell GF (Ed.), (1996) The Chlorination / Chloramination Handbook, Water Disinfection Series, AWWA Denver Co., USA.

22. Haas CN(1990) Disinfection. In: Pontius FW (Ed.), Water Quality and Treatment, $\left(4^{\text {th }}\right.$ edn), McGraw Hill, New York, USA.

23. Craun GF, Hauchman FS, Robinson DE (Eds.), (2001) Microbial pathogens and disinfection byproducts in drinking water: Health effects and management of risks. Conference Conclusions Washington, ILSI Press, USA, pp. 533-545.

24. Connell GF (1996) The chlorination/chloramination handbook. AWWA: Denver, Colorado, USA.

25. EPA (2001a) Stage 1 disinfectants and disinfection byproducts rule. EPA 816EPA Office of Water, Washington, DC, USA.

26. EPA (2015) Drinking water requirements for states and public water systems: Stage 1 and Stage 2 Disinfectants and Disinfection Byproducts Rules.

27. EPA (2016) Six-year review 3 technical support document for disinfectants/disinfection by products rules. EPA810-R-16-012. EPA Office of Water: Washington DC, USA.

28. McGuire MJ (2013) The chlorine revolution: water disinfection and the fight to save lives. Zeilig N (Ed.), AWWA: Denver, Colorado, USA.

29. Hrudey S, Backer L, Humpage A, Krasner SW, Michaud DS, et al. (2015) Evaluating evidence for association of human bladder cancer with drinking-water chlorination disinfection by-products. J Toxicol Environ Health B Crit Rev 18(5): 213-241.

30. Moreira A, Palmares C, Lopes C, Delgado L (2011) Airway vascular damage in elite swimmers. Respiratory Medicine 105(11): 1761-1765.

31. Beretta S, Vivaldo T, Morelli M, Carlucci P, Zuccotti GV (2011) Swimming pool-induced asthma. J Investig Clin Immunol 21(3): 240-241.

32. Voisin C, A Sardella, F Marcucci, A Bernard (2010) Infant swimming in chlorinated pools and the risk of bronchiolitis, asthma and allergy. Eur Respir J 36(1): 41-47.

33. Factors affecting water disinfection, CDC guideline for disinfection and sterilization in healthcarefacilities.

34. Lehtola MJ, Miettinen IT, Keinänen MM, Kekki TK, Laine O, et al (2004) Microbiology, chemistry and biofilm development in a pilot drinking water distribution system with copper and plastic pipes. Water Res 38(17): 3769-3779.

35. Sandle T (2013) Avoiding contamination of water systems. The Clinical Services Journal 12(9): 33-36.

36. Flemming HC (2002) Biofouling in water systems-cases, causes and countermeasures. Appl Microbiol Biotechnol 59(6): 629-640.

37. Fang JY, Yang X, Ma J, Shang C, Zhao QA (2010) Characterization of algae organic matter and formation of DBPs from chlor(am)ination. Water Res 44(20): 5897-5906. 
38. Chu W, Gao N, Krasner SW, Templeton MR, Yin D (2012) Formation of halogenated C-, N-DBPs from chlor(am)ination and UV irradiation of tyrosine in drinking water. Environ Pollut 161(1): 8-14.

39. Chuang YH, Tung H (2015) Formation of trichloronitromethane and dichloroacetonitrile in natural waters: precursor characterization, kinetics and interpretation. J Hazard Mater 283: 218-226.

40. Deng L, Huang C, Wang Y (2014) Effects of combined UVand chlorine treatment on the formation of trichloronitromethane from amine precursors. Environ Sci Technol 48(5): 2697-2705.

41. Dotson AD, Keen VO, Metz D, Linden KG (2010) UV/H2O2 treatment of drinking water increases post-chlorination DBP formation. Water Res 44(12): 3703-3713.

42. Krasner SW, Weinberg HS, Richardson SD, Pastor SJ, Chinn R, et al. (2006) Occurrence of a new generation of disinfection byproducts. Environ Sci Technol 40(23): 7175-7185.

43. Li J, Blatchley ER (2009) UV photodegradation of inorganic chloramines. Environ Sci Technol 43(1): 60-65.

44. Plewa MJ, Wagner ED, Jazwierska P, Richardson SD, Chen PH, et al. (2004) Halonitromethane drinking water disinfection byproducts: chemical characterization and mammalian cell cytotoxicity and genotoxicity. Environ Sci Technol 38(1): 3862-3868.

45. Acero JL, Piriou P, von Gunten U (2005) Kinetics and mechanisms of formation of bromophenols during drinking water chlorination: assessment of taste and odor development Water Res 39(13): 29792993.

46. Echigo S, Minear RA (2006) Kinetics of the reaction of hypobromous acid and organic matters in water treatment processes. Water Sci Technol 53(11): 235-243.
47. Hua G, Reckhow DA (2006) Determination of TOCl, TOBr, and TOI in drinking water by pyrolysis and off-line ion chromatography. Anal Bioanal Chem 384(2): 495-504.

48. Du JR, Peldszus S, Huck PM, Feng XS(2009) Modification of poly(vinylidene fluoride) ultrafiltration membranes with poly(vinyl alcohol) for fouling control in drinking water treatmentWater Res 43(18): 4559-4568.

49. Hammes F, Salhi E, Koster O, Kaiser HP, Egli T, et al.(2006)Mechanistic and kinetic evaluation of organic disinfection by-product and assimilable organic carbon (AOC) formation during the ozonation of drinking water. Water Res 40(12): 2275-2286.

50. Lehman LL (2009) Application of ceramic membranes with preozonation for treatment of secondary wastewater effluent. Water Res 43(7): 2020-2028.

51. (1993) Final report reported for AWWA: Mathematical modeling of the formation of THMs and HAA in chlorinated natural waters. Montgomery Watson Consulting Engineering, Denver, Colorado, USA.

52. (2012) PHA, AWWA and water environment federation, standard methods for the examination of water and waste water. American Public Health Association, Washington, USA, p. 14.

53. Clarke S, Bettin W (2009) Ultraviolet light disinfection in the use of individual water purification devices. Defense Technical Information Center.

54. Vilhunen S, Sarkka H, Sillanpaa M (2009) Ultraviolet light-emitting diodes in water disinfection. Environ Sci Pollut Res Int 16(4): 439-442.

For possible submissions Click below: 